C./ITOOLSSMMS/CUP.NEW/16725874/WORKINGFOLDER/CABRERA_CAMACHO/9781108488273C08.3D 209 [209-231] 26.2.2.2019 11:26AM

III

Linearization 


\section{Merge, Restructuring, and Clitic Climbing In Spanish}

\section{Pascual José Masullo}

\subsection{Introduction}

A well-studied phenomenon in Spanish (and in Romance languages in general) is clitic placement in constructions with so-called restructuring verbs, such as querer "want," deber "must," poder "can/may," soler (habitual aspect), empezar "begin," estar "be" - which are sometimes dubbed semi-auxiliary verbs, since they express modality and aspect - as well as the true auxiliary haber "have" (see Burzio, 1986; Cardinaletti \& Shlonsky, 2004; Cinque, 2004, 2006; Perlmutter, 1983; Strozer, 1976; among many others). What is especially noteworthy about these constructions is that, when pronominal clitics are used, these may be associated either with the main finite verb or the lexical verb in a non-finite form. ${ }^{1}$ The phenomenon, referred to in the literature as "clitic climbing," is illustrated in (1) and (2) below:
a. Pablo quiere ver-lo ${ }^{2}$.
Paul wants see-CL
"Paul wants to see it."
b. Pablo lo quiere ver.
Paul CLITIC wants see
"Paul wants to see it."

${ }^{1}$ While it is true that a special clitic will appear as proclitic or enclitic depending on the finiteness of the host, in this chapter I assume the perhaps unorthodox position that the actual morphophonological process of procliticization (before the host) or encliticization (after the host) constitutes an independent, language-specific phenomenon, and so is not addressed here (see Section 8.2). It is no wonder that we find a great deal of variation in this area, both synchronic and diachronic. For our purposes, what is relevant is which verb within the complex hosts the clitic, regardless of its "morphotactics." Moreover, as expected, Romance languages evince significant differences among one another. In this chapter, we restrict our attention to present-day "pan-hispanic" Spanish, except when so noted.

2 The reader is reminded that Spanish participles cannot host clitics, so that we do not find *He hecholo, "I have done it." 
(2) a. Pablo pudo brindar-le ayuda a su amiga.

Paul could offer-CL help to his girlfriend

"Paul was able to offer his girlfriend help."

b. Pablo le pudo brindar ayuda a su amiga.

Paul CLITIC could offer help to his girlfriend

"Paul was able to offer his girlfriend help."

This alternation is possible with all kinds of "special" or pronominal clitics not only accusative and dative, but also the different classes of se (reflexive, anticausative, impersonal, etc.). In (3) below, the clitic is anticausative (Zubizarreta, 1987):

a. El vidrio pudo haber-se roto. $^{2}$

the glass could have-CL broken

"The glass could have broken."

b. El vidrio se pudo haber roto.

The glass CLITIC could have broken

"The glass could have broken."

Besides, as (3) above and (4) below show, the alternation in clitic placement under discussion is found in complex restructuring constructions with more than one auxiliary or semi-auxiliary verb:
a. María puede querer comprar-lo.
Mary may want buy-CL
"Mary may want to buy it."
b. María lo puede querer comprar.
Mary CLITIC may want buy
"Mary may want to buy it."

More importantly, the restructuring may be partial, in which case the clitic does not have to "climb" all the way up to the finite verb. Below we show a third possibility for (4):

$$
\begin{aligned}
& \text { María puede querer-lo comprar. } \\
& \text { Mary could want-CL buy } \\
& \text { "Mary may want to buy it." }
\end{aligned}
$$

In principle, clitic climbing is possible with complexes containing any number of verbs, as in (6) below. However, for processing reasons, we rarely find instances with more than three verbs.

$$
\begin{aligned}
& \text { a. ? El hombre debió (de) haber querido poder empezar } \\
& \text { the man must have wanted can begin } \\
& \text { a comprender-lo. } \\
& \text { to understand-CL } \\
& \text { "The man must have wanted to be able to begin to understand him." }
\end{aligned}
$$



b. ?? El hombre lo debió (de) haber querido poder the man CLITIC must have wanted can empezar a comprender. begin to understand "The man must have wanted to be able to begin to understand him."

Sentence (6a) already sounds awkward enough, whereas (6b) is unacceptable, but, again, this fact is independent of the syntactic component proper.

As we have pointed out, clitic climbing is contingent on restructuring, so that, if the latter cannot take place for independent reasons (to the best of my knowledge, a principled account of the syntactic and lexical properties required for restructuring is still unavailable), clitic climbing will be precluded, as shown in (7) and (8) below, though a certain degree of variation must be allowed for.
a. A Pedro parece gustar-le.
to Peter seems like-CL
"Peter seems to like it."
b. *A Pedro le parece gustar.
to Peter CLITIC seems like
"Peter seems to like it."
a. Juan disfruta ayudándo-la.
John enjoys helping-CL
"John enjoys helping her."
b. * Juan la disfruta ayudando.
John CLITIC enjoys helping
"John enjoys helping her."

As anticipated, in generative grammar, the process whereby we get the (b) alternations has been described as clitic climbing, a metaphor suggesting that the clitic has moved upward from its original theta (or "deep") position to a higher position (Kayne, 1989, 1991; Perlmutter, 1983), sometimes across more than one verb. However, in this chapter, I set out to offer a simple (though hopefully not simplistic) account of this time-honored problem. I propose that a movement account is rendered unnecessary by a more sophisticated system of Merge (Chomsky, 1995), which crucially relies on feature-checking and feature-inheritance, and which allows for equally convergent derivations of the same sentence (Section 8.4). I will also show that our approach can easily tackle clitic clusters (Section 8.5) as well as dialectal variation (Section 8.6). Finally, I argue that clitic climbing is similar to other alternating phenomena which result from the order in which the different items in the numeration are merged, given a choice (Section 8.7). However, before proceeding to spell out this analysis in detail and suggesting possible extensions thereof, a discussion 
of certain crucial properties of Spanish verbal clitics is in order (Section 8.2). The arguments in support of a movement analysis must also be reviewed (Section 8.3).

\subsection{Assumptions about "Special" Clitics in Spanish}

Clitics in general, but special clitics in particular, have traditionally constituted a challenging problem for a theory of grammar that purports to relate different levels of representation, and tries to account for the general design of language. Offering a comprehensive solution to the problem of cliticization, no doubt a prototypical interface phenomenon, is certainly beyond the scope of this modest contribution (see Kayne, 1975; Saltarelli, 1989; Sportiche, 1997; Uriagereka, 1995; among others). However, the not uncontroversial assumption will be made here that, much in the same way as the morphosyntax of simple clitics shows a mismatch with respect to its morphophonology, so the morphosyntax of special clitics need not mirror its morphophonological realization, and vice versa. Among other things, this assumption entails that the Mirror Principle (Baker, 1988) is insufficient, at best, to explain fully the order in which clitics appear, relative to the verb.

Therefore, we should not expect the syntactic component to account for language-specific co-occurrence restrictions, clitic "templates," displacement of features from one clitic to the next, phonological adjustments, and the like (Halpern, 1998). In particular, contrary to what has been argued elsewhere, I will assume here that whether a clitic may or must appear as an enclitic or proclitic need not be explained by the syntax alone, especially when one considers the astounding differences and arbitrariness found among the various Romance languages (see, for example, Authier \& Reed, 2009). Below, I partially illustrate the quirky and arbitrary behavior alluded to: the semireflexive anticausative clitic must precede the dative clitic in Spanish (9a), whereas the opposite is true in Italian (9b), as well as in child language (9c). While impersonal se must precede an accusative clitic in Spanish (10a), the opposite holds in Italian (10b), and so on:
a. Se me perdieron las llaves.
CL-R me lost the keys
"I have lost the keys." (lit. "The keys have lost on me")
b. Mi si sono perdute le chiavi.
me CL-R are lost-PL the keys
"I have lost the keys."
c. $\% \mathrm{Me}$ se perdieron las llaves.
$\mathrm{Me} \quad \mathrm{CL}-\mathrm{R}$ lost the keys
"I have lost the keys." (lit. "The keys have lost on me") 

a. Se lo considera el mejor músico actual. CL-IMP CL-ACC consider the best musician actual "He is considered the best contemporary musician."
b. Lo si ritiene il miglior musicista attuale. CL-ACC CL-IMP consider the best musician actual "He is considered the best contemporary musician."

Thus, we will content ourselves with simply explaining which verb within a complex a clitic associates with syntactically, regardless of its ultimate realization in the morphophonology.

The other issue concerns the morphosyntax of verbal clitics, which are clearly at the interface between morphology and argument/theta structure, and encode a wide range of grammatical features: reflexive or non-reflexive; case features: accusative or dative; number: singular or plural; person: first, second, or third. Moreover, there is still the question of whether they are agreement markers (Suñer, 1988) or incorporated pronouns. In languages such as Standard Italian, where clitic doubling is disallowed, the best account is no doubt in terms of $\mathrm{X}^{\mathrm{O}}$ incorporation - for example, à la Baker (1988). However, Spanish shows obligatory clitic doubling with full pronouns in all varieties (11). Likewise, as is well known, varieties such as River Plate permit doubling (at least) with animate DPs (12). These facts would seem to render implausible an account in which the clitic is a full argument for theta purposes.

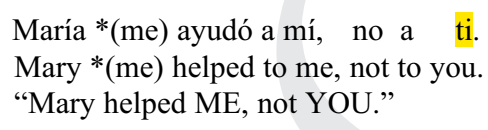

(12) Anoche (lo) vimos a nuestro profesor de gramática.

Last night (him) saw to our professor of grammar

"Last night we saw our grammar professor."

It is not my aim to attempt to solve this long-debated problem in generative grammar. However, the true syntactic nature of clitics (as full pronouns or as agreement markers) will turn out to be irrelevant, since our proposed account does not hinge on it. Nor does a movement account, for that matter, as we shall see in the following section.

\subsection{Movement Account}

Reviewing the vast literature on clitic climbing is certainly not feasible here, so, for the sake of simplicity, we will sketch two possible idealized analyses permitted in GB/PP: if a clitic is analyzed as a true argument of the verb, then we can propose head movement from its original $\theta$-position, i.e. the lower $\mathrm{V}$, to the higher $\mathrm{V}$, onto which it adjoins. This is schematized in (13) below: 


$$
\text { Pablo } l_{i} \text { quiere ver } t_{i}
$$

If, on the other hand, as has been argued by others, including Strozer (1976) and Suñer (1988), clitics mark object agreement, and, moreover, we adopt the postulation of AGRO projection (Bobaljik \& Phillips, 1993; Chomsky,1995; Phillips, 1993), an account should be proposed in which the clitic moves from the AGRO above the verb with which it is originally associated, to the AGRO of the upper verb, as shown in (14):

\section{(14) Pablo [AGROP $l_{\mathrm{i}}$ quiere [AGROP $\mathrm{t}_{\mathrm{i}}$ ver pro $_{\mathrm{i}}$ ]}

This analysis assumes that the case-checking domain of the object (the empty category pro in this case) varies according to whether restructuring has taken place or not. The checking domain is the AGRO above the embedded verb if no restructuring has taken place. However, if there is restructuring, the checking domain is the AGRO above the (semi) auxiliary.

The arguments that can be advanced for a movement account are standard: firstly, in conformity with the Uniformity of Theta Assignment Hypothesis (UTAH) (Baker, 1988), the (b) alternants in (1) and (2) should be derived from their (a) counterparts, since the latter are basic on account of the lower verb assigning both a $\theta$-role and case, i.e. the clitic is an argument of (or agrees with the argument of) the embedded verb. In fact, most restructuring verbs are neither theta nor case-assigners: soler (a raising verb denoting habitual aspect), as well as estar "be" and the auxiliary haber "have" are good examples. Secondly, clitic climbing is subject to locality constraints, just like Whmovement. For example, extraction of cómo "how" in (15) below is blocked by NEG, a minimality barrier according to Rizzi (1990). By the same token, NEG prevents raising of the clitic in (16b) (see Masullo, 1992a, for a Relativized Minimality account):

* ¿Cómo ${ }_{\mathrm{i}}$ dijo Juan que no arregló su auto $\mathrm{t}_{\mathrm{i}}$ ? How said Juan that not fixed his car

* How ${ }_{\mathrm{i}}$ did John say that he did not fix his car $\mathrm{t}_{\mathrm{i}}$ ?
a. Pablo quisiera no ver-la.
Paul would.like not see-CL
"Paul would like not to see her."
b. * Pablo la quisiera no ver Paul CLITIC would.like not see "Paul would like not to see her."

That is, the trace cannot be antecedent-governed by the clitic (see Baker 1988 on the ECP in head movement), just as the trace of how cannot be governed by its antecedent, owing to the presence of the NEG barrier. This is schematized in (17): 
* Pablo la $a_{i}$ quisiera no ver $\mathrm{t}_{\mathrm{i}}$.

Paul CLITIC $_{i}$ would-like not see $t_{i}$

"Paul would like not to see her."

Likewise, the complement-adjunct asymmetry encountered in Wh-movement ([18a] and [18b]) applies to clitic climbing as well:
a. ¿Qué fue a hacer $t_{i}$ Juan?
what ${ }_{i}$ went to do $t_{i}$ John?
"What did John go to do?"
b. ${ }^{*}$ ¿Qué ${ }_{\mathrm{i}}$ fue para hacer $\mathrm{t}_{\mathrm{i}}$ Juan? what ${ }_{i}$ went for do $t_{i}$ John?
"What did John go in order to do?"

In (18a), que "what" is extracted out of the $a$-PP, the complement of the verb fue "went," so the ECP is complied with. In (18b), however, the PP introduced by para is unselected, since it is a purpose adjunct acting as a barrier for antecedent-government of the trace of the extracted $W h$-element (i.e., the Condition on Extraction Domains is not upheld). Now consider (19):
a. Juan fue a abri-le la puerta.
John went to open-CL the door
"John went to open the door for her/him."
b. Juan le fue a abrir la puerta.
John CLITIC went to open the door
"John went to open the door for her/him."
(The $a$-phrase following fue is a complement.)

Example (19b) mirrors the situation in (18a), with clitic movement instead. Since le is extracted out of the complement of fue (the PP introduced by $a$ ), no ECP violation is incurred. However, (20b) below mirrors the situation in (18b), the clitic le moving out of the para-PP adjunct: ${ }^{3}$
a. Juan fue para abrir-le la puerta. John went for open-CL the door
"John went to open the door for her/him."
b. * Juan le fue para abrir la puerta. John CLITIC went for open the door "John went to open the door for her/him." (The para-phrase is a purpose adjunct.)

Elegant and cogent though it may seem, a movement account is not without its problems. As all the examples provided above clearly show, clitic climbing is

\footnotetext{
3 Our assumption that the $a$-PP is a complement, while the para-PP is an adjunct, also finds confirmation in the fact that only the first can be combined with ir "go" to form the periphrastic future. A detailed comparison of the behavior of motion verbs taking complements and that of motion verbs taking adjuncts is still outstanding.
} 
syntactically optional. That is, nothing in the syntax would seem to force the (b) rather than the (a) alternants. ${ }^{4}$ Although this is not a problem in standard GB/PP, it is indeed a problem in the Minimalist Program, in which movement is a last-resort operation triggered by the need to check some strong formal feature, so that it is heavily restricted by Economy considerations (Chomsky, 1995). In other words, nothing should force us to derive (b) from (a), if we can avoid it, since (a) is all right as is, and, moreover, its derivation is less costly than that of (b), which requires an extra (unnecessary) step. A possible way out of this dilemma is to claim that the obligatoriness or optionality of clitic climbing is dependent on whether restructuring has taken place or not. But this argument is circular at best, since it still leaves us with having to account for the obligatoriness or optionality of restructuring in the first place. ${ }^{5}$ However, optionality is not a problem in our account, since it stems from equally economical derivations, all things being equal.

Finally, we must mention the fact that, although we have used the classical machinery available in GB/PP to deal with movement, a Copy theory will not fare any better, since the derivation of clitic climbing would involve four steps: Merge of clitic + Copy + Remerge Copy + PF-erasure of clitic first merged. In any case, to be fair, the reader is reminded that head-movement is dealt with at $\mathrm{PF}$ in recent minimalist accounts.

\subsection{A New Proposal}

I would like to propose instead that clitic climbing is an epiphenomenon indirectly resulting from the order in which Merge (Chomsky, 1995) takes place, i.e. it is a function of restructuring, understood, in turn, as complex predicate formation, i.e. incorporation of a verb with full lexical content into an auxiliary or "semi-auxiliary" verb (sometimes optional, sometimes mandatory, as we shall see). Baker's (1988, 1996) classical account of incorporation has been in terms of head movement, overt in the case of polysynthetic languages, and covert (i.e. at LF) in the case of restructuring or "reanalysis" in nonpolysynthetic languages such as Spanish, Italian, and so on.

We specifically adopt Contreras \& Masullo's (1999, 2002) account of Merge, briefly outlined below:

(i) Merge is motivated by feature-checking (Cf. Chomsky, 2000, etc.), just like Move, though it is still the "default" operation given for free by the computational system, and so, unlike Move, is not at all costly.

4 Actually, if the content verb is in its participial form, then "climbing" seems to be obligatory. But this is due to the independent prohibition of combining clitics with participial forms of verbs, as was pointed out in note 2 .

5 Baker's (1988) account of complex predicate formation and incorporation would seem to run into the same problem, except in cases in which morphological constraints, such as the Stray Affix Filter, force head movement. 
(ii) The features that trigger Merge can be selectional or intrinsic. This means that it is the theta requirements of a verb that trigger Merge of a predicate with its arguments.

(iii) Intrinsic features are interpretable.

(iv) Selectional features are uninterpretable (henceforth, $u$ ).

(v) Only uninterpretable features need to be checked (and deleted).

(vi) Interpretable features may be checked, but they are not deleted.

(vii) Interpretable features are weak.

(viii) Uninterpretable features may be strong or weak.

(ix) Weak unchecked features percolate to the category resulting from Merge.

(x) Strong unchecked features do not percolate, except in the case of "complex predicate formation" (see xii).

(xi) Standard cases of feature-checking may be reinterpreted as automatic by-products of the operation Merge (e.g. case and agreement can be checked by a DP as soon as Merge combines the verb and the DP).

(xii) A head can merge with another head, both "pooling" their argument structure.

Here we make the additional assumption that clitics can check $\theta$ (selectional), case, and agreement features by themselves.

As we shall see, (xii) plays a crucial role in our analysis, since it dispenses with head movement for complex predicate formation (see also Masullo, 1998). Instead, our account relies on direct Merge of heads with concomitant percolation of selectional features. Adopting this analysis has the advantage of not having to derive the (b) sentences from the (a) ones, as a UTAH-based headmovement analysis would require, so that the question of optionality raised above ceases to be a problem.

Below, we apply our analysis to the constructions under consideration in this chapter. Let us first take sentence (1a) above, repeated with bracketing in (21):

Pablo [quiere [ver-lo] $]^{6}$

As the bracketing suggests, the derivation of (21) proceeds as follows: lo is merged with the embedded verb (ver) first, checking immediately its selectional D (theme) feature, as well as accusative case. In the next step, [ver-lo] checks the V (say, event) feature of quiere. Since lo is associated with a nonfinite verb, independent morphophonological requirements of Spanish dictate that the clitic be realized as an enclitic, but this is actually irrelevant for our purposes, since all that matters is to determine which of the two verbs the clitic is associated with, as was pointed out above. In this case, it is the content verb

\footnotetext{
${ }^{6}$ We are leaving out of our account Merge of Tense and of the external argument.
} 
ver "see," given the order and motivation of Merge. This is shown in the tree diagram below:

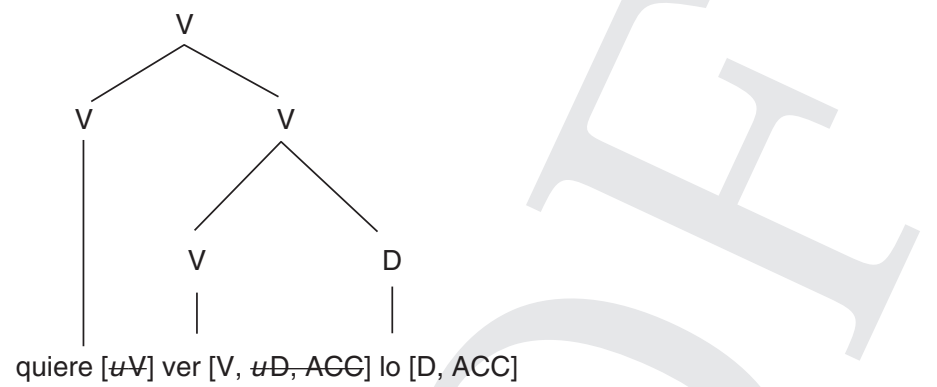

The derivation of (1b), repeated as (23) below, proceeds differently, since we first merge the two verbs (thus obtaining "restructuring", as observed), before proceeding to check their selectional features:

$$
\text { Pablo [lo [quiere ver]] }
$$

That is, ver checks the $\mathrm{V}$ (event) feature of quiere (quiere just selects for a $\mathrm{V}$, so in terms of Bare Phrase Structure, it is irrelevant whether V is a head or a maximal projection). After merging the two heads, the unchecked features of ver (both $\theta$ and case, i.e. D (theme) and ACC case) percolate to the complex verb obtained, which are checked "belatedly" when we merge it with $l o$. Since the clitic is associated with a finite verb in this case, independent morphophonological requirements of Spanish dictate that the clitic be realized as a proclitic (cf. Quererlo ver es una tentación "Wanting to see it is a temptation," in which the "climbed" clitic is still an enclitic, given the non-finite nature of querer). As in the case of (21), what is relevant for our analysis is whether the clitic is associated with the main or (semi-) auxiliary verb. This in turn is determined by the order of the Merge operations. The tree in (24) below sketches out the derivation:

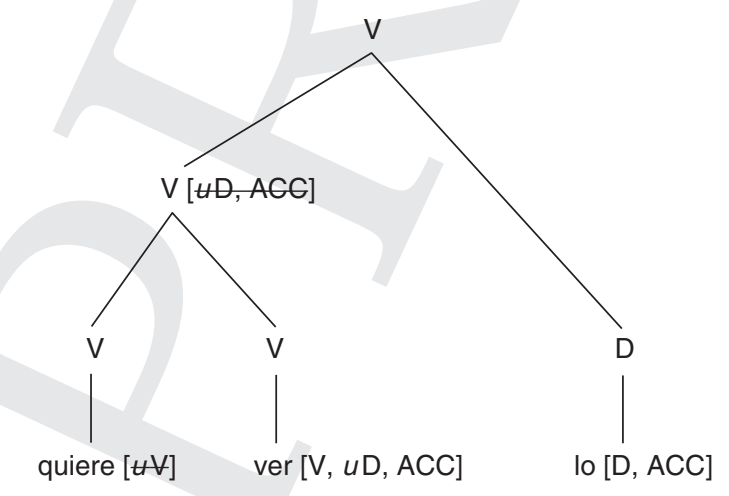


I would like to point out that there is another way to deal with our alternations, also without clitic movement. If we follow Baker's (1988) analysis of restructuring in terms of LF movement, we can claim that the clitic attaches to the main verb if no reanalysis has taken place, while it attaches to the (semi-) auxiliary verb in the case of head movement at LF. However, this still leaves us with the problem of having to account for the optionality of reanalysis (upon which clitic placement is contingent), a problem that our direct Head-Merge account does not face. Besides, head movement (a costly last-resort operation) is still required at LF. However, this alternative analysis is similar to the one being proposed here, in that there is no actual clitic movement in the (b) alternants. Instead, the clitic associates with the head of the complex, i.e. the (semi-)auxiliary, which, being the incorporator, remains the head (Baker, 1988).

If complex predicate formation is obligatory for independent reasons (most notably with causative hacer), ${ }^{7}$ clitic climbing will necessarily be obligatory by extension, but once again the movement is only apparent - that is, it is a derived phenomenon. Consider (25):

$$
\begin{aligned}
& \text { a. Juan le hizo leer el libro. } \\
& \text { John CLITIC made read the book } \\
& \text { "John made him read the book." } \\
& \text { b. * Juan hizo leer-le el libro. } \\
& \text { John made read CLITIC the book } \\
& \text { "John made him read the book." }
\end{aligned}
$$

In our view of Merge, the obligatoriness of complex predicate formation is explained by proposing a strong $[+\mathrm{V}]$ feature on the light verb hacer, which calls for immediate Merge with the lexical verb, prior to any other Merge operation. This process can be likened to the situation encountered in languages like Chichewa, in which the causative verb is expressed by a bound morpheme, and so, in accordance with the Stray Affix Filter, must obligatorily incorporate the main verb (Baker, 1988, 1996). We do not flesh out the details here.

We now need to address the question of locality, discussed in Section 8.3 above. How do we deal with it in our account? The answer is straightforward: the ungrammaticality of sentences such as (16b) and (20b) (repeated below as [26] and [27], respectively) is now explained in terms of the impossibility of complex predicate formation, rather than in terms of barriers for clitic movement.

\footnotetext{
7 I am aware of the degree of idealization involved in this statement. Not all varieties of Spanish behave in the same way when it comes to clitic clustering with causative hacer - or other restructuring verbs, for that matter.
} 


$$
\begin{aligned}
& \text { * Pablo la quisiera- no- ver. } \\
& \text { Paul CLITIC would.like-not-see } \\
& \text { "Paul would like not to see her." } \\
& \text { * Juan le fue para abrir la puerta. } \\
& \text { John CLITIC went for open the door } \\
& \text { "John went to open the door for her/him." }
\end{aligned}
$$

We have argued that (26) is ungrammatical because NEG prevents the incorporation of the lexical verb into the (semi-)auxiliary verb. For this argument to go through, however, we need to make the further assumption that complex predicate formation results from the incorporation of a bare (unspecified) head (cf. Guasti, 1997; Masullo, 1990). This is corroborated in the case of causative constructions:

$$
\begin{aligned}
& \text { a. Juan hizo llorar a Marta. } \\
& \text { John made weep to Martha } \\
& \text { "John made Martha weep." } \\
& \text { b. * Juan hizo no llorar a Marta. } \\
& \text { John made not weep to Martha } \\
& \text { "John made Martha not weep." }
\end{aligned}
$$

In our account, complex predicate formation is blocked in (b) because the embedded verb is no longer a bare head (being specified by NEG), and so the output of Merge cannot inherit the relevant $\theta$ and case features. Therefore, a pronominal clitic will not be able to check them later. ${ }^{8}$

How do we deal with (27) in our approach? I have claimed that the purpose clause introduced by para "for" is not selected by the verb, but rather checks an intrinsic feature of a higher head (e.g. event). So we now capture the complement/adjunct asymmetry in the following terms: a head can only merge with another head that it selects for. In contrast, in Baker (1988), the ungrammaticality of (27) is accounted for in terms of an ECP violation.

Finally, I suggest that, in our approach, UTAH can still be maintained, but in revised form:

$$
\begin{aligned}
& \text { UTAH (reformulated version): } \\
& \text { Thematic paraphrases check the same selectional features, though not neces- } \\
& \text { sarily the same formal features. }
\end{aligned}
$$

\subsection{Clitic Clusters}

If several clitics are involved, then they must appear as a cluster. Moreover, if complex predicate formation has not taken place, the clitic cluster must be

\footnotetext{
${ }^{8}$ An alternative account is that operators in general prevent the percolation of features, given the semantic opacity they introduce. Likewise, if we adopt a movement account for restructuring, we can still argue that NEG acts as a barrier giving rise to an ECP violation.
} 
associated with the selecting verb, as illustrated in (30a). Its counterparts (30b) and (30c) are ungrammatical because the clitics are dissociated, and no possible derivation could yield those sequences: In the case of (30b), darlo is no longer a bare head, so it cannot be merged directly with querer and form a complex predicate with it, by the requirement that incorporated verbs be bare. Consequently, there can be no percolation of the selectional features of dar, and so we cannot license merge of the clitic le with the semi-auxiliary. The same applies to (30c), but in reverse.
a. Juan quiere dár-se-lo.
John wants give-CL-CL
"John wants to give it to him/her."
b. * Juan [le [quiere [dar-lo]]]
John CL.DAT wants give-CL.ACC
"John wants to give it to him/her."
c. * Juan [lo [quiere [dar-le]]]
John CL.ACC wants give-CL.DAT
"John wants to give it to him/her."

In contrast, if complex predicate formation has taken place, clitics must appear as a cluster, as shown in (31a). The ungrammaticality of (31b) and (31c) is accounted for in the same way as that of (30b) and (30c), again in reverse.
a. Juan se lo quiere dar.
John CL.DAT CL.ACC want give
"John wants to give it to him/her."
b. * Juan le quiere dar-lo.
John CL.DAT wants give-CL.ACC
c. * Juan lo quiere dar-le. John CL.ACC wants give-CL.DAT

On the other hand, given the mandatory nature of complex predicate formation in the case of causative hacer, at least in most varieties, the equivalent of (30a) is ruled out from the outset, along with the equivalent of the other ungrammatical derivations with a verb such as querer:

$$
\begin{aligned}
& \text { a. * Pablo hizo lavár-se-lo. } \\
& \text { Paul made wash-CL-CL } \\
& \text { "Paul made her/him wash it." } \\
& \text { b. * Pablo le hizo lavar-lo. } \\
& \text { Paul CL made wash-CL } \\
& \text { "Paul made her/him wash it." } \\
& \text { c. *Pablo lo hizo lavarle. }
\end{aligned}
$$

Crucially, when complex predicate formation takes place, whether optionally or obligatorily, as in causative constructions, theta and case assignment are 
determined by the complex as a whole (subject to Baker's Case Frame Preservation Principle), and not by each individual verb. That is, $\theta$-roles, cases, and, crucially, clitics, are "pooled," which is why they must appear as a cluster associated with the (semi-)auxiliary verb. Independent evidence of this "pooling" is provided by the following facts: First, two clitics with the same case are impossible (for example, one assigned by hizo and one by leer in [33b]):
a. Juan hizo Leer el libro a María.
John made read the book to Mary
"John made Mary read the book."
b. * Juan la lo hizo leer. John CL.ACC CL.ACC made read "John made her read it."

Secondly, anticausative se-"absorption" is possible in causative constructions in Italian (Burzio, 1986), as well as in some varieties of Spanish (but see Zubizarreta, 1987), as illustrated in (34). This is due to the fact that the causative verb provides an external argument for the complex as a whole, thus rendering dispensable and optional the anticausative clitic se, which shows precisely suppression of the external argument:
a. La vela se apagó.
the candle CLITIC extinguished
"The candle went out."
b. El viento hizo apagar la vela. the wind made extinguish the candle "The wind blew out the candle."
c. El viento hizo apagar-se la vela. the wind made extinguish-CL the candle "The wind blew out the candle."

If complex predicate formation cannot occur, e.g. with perception verbs (Masullo, 1990), then we expect each clitic (or clitic cluster) to be independently associated with its corresponding verb, and to separately check the case (and $\theta-$ ) feature of each verb:
a. Pablo me vio saludar-la.
Paul CL.ACC saw greet-CL.ACC
"Paul saw me greet her."
b. * Pablo me la vio saludar. Paul CL.ACC CL.ACC saw greet "Paul saw me greet her."

Finally, the following facts lend extra support to our account of perception verbs: First, two accusative clitics are possible, as in (35a) above, and, 
moreover, anticausative-se absorption is impossible (36c), which we take as clear evidence that no $\theta$ or case (and therefore, no clitic) "pooling" has taken place. This implies that each clitic (cluster) is merged separately in different steps of the derivation.
a. La vela se apagó.
the candle CLITIC extinguished
"The candle went out."
b. Juan vio la vela apagar-se.
John saw the candle extinguish-CL
"John saw the candle go out."
c. * Juan vio apagar la vela. John saw extinguish the candle "John saw the candle go out."

\subsection{Dialectal Variation}

In this section, I briefly explore how our approach to restructuring and clitic climbing can tackle some well-known variations in Spanish concerning the behavior of clitics (see Hurtado, 1984; Jaeggli, 1986; Lipski, 1994 - and references therein, among others). First, let's examine "clitic doubling," best represented by River Plate Spanish. As (37) shows, it is possible to have a clitic even in the presence of a DP object.

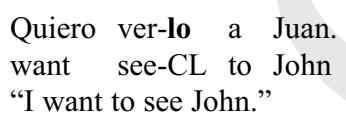

To obtain (37), I propose the following derivation: Merge of verlo a Juan precedes Merge with quiero (i.e. no complex predicate has been previously formed). The clitic only checks agreement (i.e. here it is an agreement marker and not a true argument). Case and selectional features are checked by Juan, the true argument in this type of construction. Now consider (38):

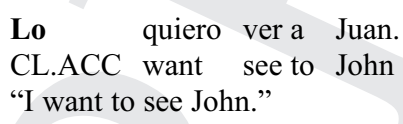

Merge of quiero ver precedes Merge with a Juan (i.e. a complex predicate has been formed). The clitic is therefore associated with the complex verb, which has inherited the $\theta$-role and accusative case from ver. Again, it only checks agreement, since it is Juan, the true argument, that checks selectional and case 
features (of the complex verb, in this case). ${ }^{9}$ As I pointed out at the outset, our account is compatible with both views: clitics as agreement markers, or clitics as incorporated arguments. In fact, a clitic behaves as one or the other depending on its syntactic environment.

Next, we examine "clitic reduplication," as is illustrated, for example, by some varieties of Chilean Spanish. As (39) below shows, it is possible to have the same clitic appear twice - with the main verb, as well as with the semiauxiliary - or "circumfixing" the complex:

$$
\begin{aligned}
& \text { Lo vamos a comprar-lo. } \\
& \text { CL are.going to buy-CL } \\
& \text { "We are going to buy it." }
\end{aligned}
$$

We explain clitic reduplication by proposing the following derivation: complex predicate formation has occurred. Therefore, it is the first occurrence of the clitic that checks the selectional and case features that have percolated from comprar. In our view, the enclitic is a resumptive pronoun in this case - that is to say, it redundantly checks the features of comprar, despite the fact that they have percolated.

\subsection{Extensions}

In this section, I try to demonstrate that clitic climbing forms a natural class with apparently disparate phenomena. In the constructions examined below, I show that the alternations we find depend on the order in which Merge has occurred. First, let's consider a common alternation in Spanish involving case, i.e. genitive and dative. ${ }^{10}$ In (40a), the theme argument la oscuridad "the dark" receives inherent case (realized by means of de "of"), whereas in (40b) it receives dative case from the verbal complex (realized by means of $a$ and the clitic le):

a. Los niños tienen miedo de la oscuridad. the children have fear of the dark "The children are afraid of the dark."

b. Los niños le tienen miedo a la oscuridad. the children CLITIC have fear to the dark "The children are afraid of the dark."

9 The analysis outlined in this section extends naturally to clitic doubling in dative constructions (which is almost always obligatory in most varieties of Spanish), as well as obligatory clitic doubling in all dialects of Spanish when the argument is expressed by a personal pronoun.

10 This alternation is very productive in Spanish (and, with some variations, in Romance in general), and includes "Possessor Raising," for which we can propose a similar analysis (cf. Masullo, 1992, for a more "orthodox" account in terms of real head movement à la Baker). 
Notice that (40) illustrates a "light" verb construction, so that it has to depend on a contentive noun for $\theta$-role assignment. I claim that, if no complex predicate formation takes place (... [tienen [miedo [de la oscuridad]]] ...), la oscuridad checks the inherent genitive case of the noun miedo, marked by de "of.". This gives us (40a), whose derivation is briefly summarized in (41):

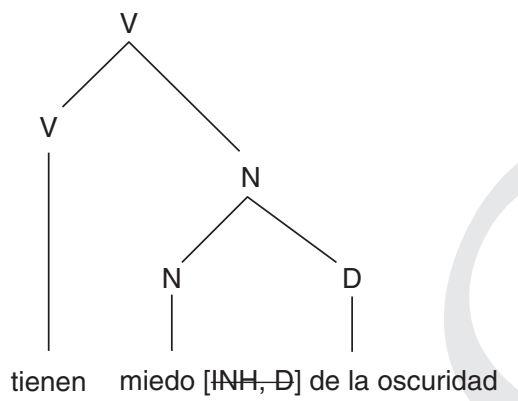

However, light verb constructions such as those exemplified in (40) are quite amenable to "restructuring" or complex predicate formation. We therefore claim that (40b) is obtained by first merging the light verb tener "have" with the psych-noun miedo "fear" (... [le [tienen miedo] a la oscuridad] ... .), so that oscuridad gets structural dative case from the complex verb, marked by $a$ and the agreeing clitic le. The derivation for (40b) is outlined in (42):

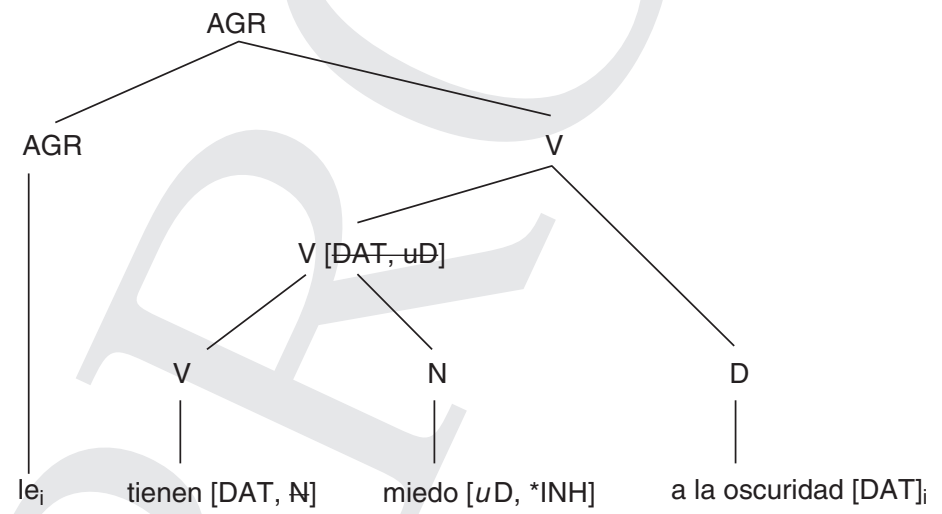

Next, we look at an alternation in Italian involving auxiliary selection with verbal complexes in which the lexical verb is unaccusative (Burzio, 1986). As (43) shows, both auxiliaries essere and avere are possible in the compound tenses, prescriptive considerations aside: 
(43)
$\begin{array}{lll}\text { a. Maria è volut-a } & \text { partire da Roma. } \\ \text { Mary is wanted-FEM leave from Rome }\end{array}$
"Mary has wanted to leave Rome."
b. \% Maria ha voluto partire da Roma.
Mary has wanted leave from Rome
"Mary has wanted to leave Rome."

Although more tentatively, I also suggest that an account that appeals to order of Merge is worth pursuing. In (43a), complex predicate formation has taken place (i.e. the two verbs are merged first, before merging the arguments), so that the corresponding "unaccusative" feature of partire percolates, and the auxiliary essere "be" can see it, as outlined in (44):

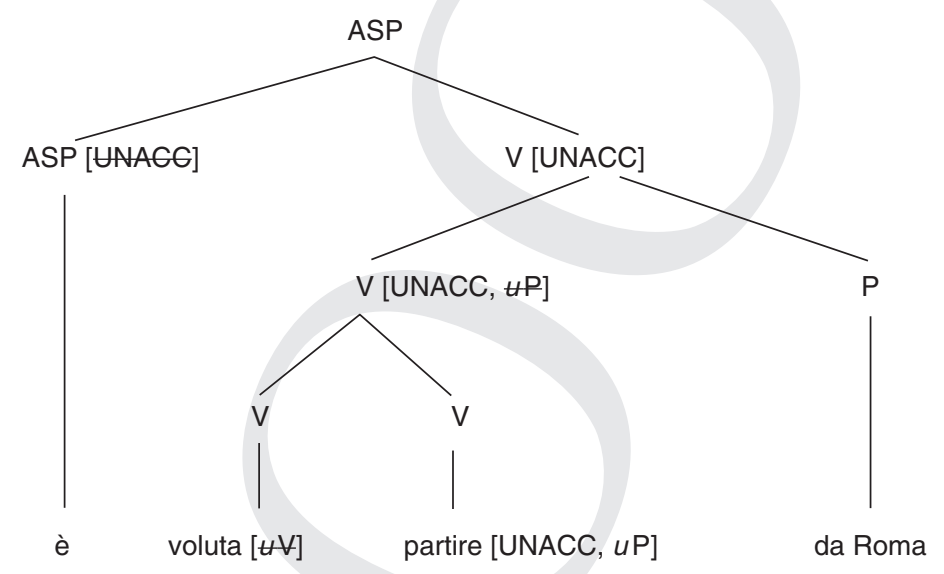

In contrast, complex predicate formation has not obtained in (43b), so the selecting auxiliary can only see the $[\mathrm{ACC}]$ feature of voluto, which is why it is avere, as shown in (45) below:

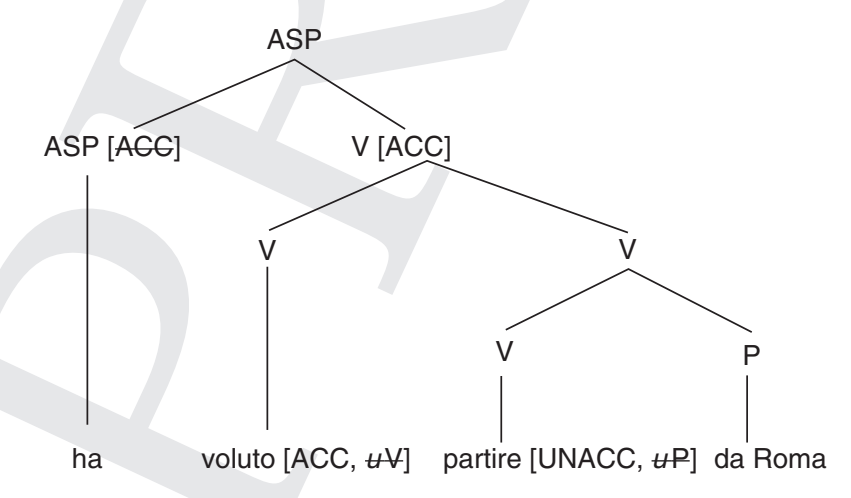


To conclude this section, I will mention an account of agreement alternations (singular vs. plural) in certain impersonal constructions in Spanish proposed by Bertora (2016), which also exploits order of Merge:
a. Me falta [corregir tres exámenes].
Me-DAT lack-SG grade three exams
"I still have to grade three exams." / "I still have three more exams to grade."
b. Me [falta-n corregir] tres exámenes.
Me-DAT lack-PL grade three exams
"I still have to grade three exams." / "I still have three more exams to grade."

As the bracketing suggests (46a) results from first obtaining [corregir tres exámenes] and then merging it with the finite verb falta. Given this order of merge, the impersonal construction will be in the singular by default. However, if we first obtain the complex predicate falta-corregir, as in (46b), the deep object of corregir will trigger agreement (and perhaps in addition get nominative case instead of accusative). Once again, the alternants are a by-product of the order in which Merge proceeds. The reader is referred to Bertora (2016) for a full discussion.

\subsection{Conclusions}

I have argued that clitic climbing is an epiphenomenon, derived from the order in which Merge operations take place, i.e, it is a by-product of "reanalysis" or "restructuring," understood as complex predicate formation. I have also argued that a movement analysis of complex predicate formation in general can be dispensed with in favor of Direct Merge of verbal heads, with concomitant fusion and "pooling" of features. I have claimed that this analysis is not only much more economical, since no movement (a last-resort operation) is involved, but also superior, since the apparent optionality involved in clitic climbing and head movement ceases to be a problem. As we have seen, there is actually no "optionality" once a certain order of Merge has been set in motion. In other words, "optionality" should be the norm, not the exception, so long as there are no independent demands such as strong feature-checking to be satisfied, and so long as both "paths" involve the same number of steps and thus uphold Economy.

In addition, I have shown that clitics may be argumental (in which case, they check both selectional and case features), or agreement markers (in which case, they only check agreement with an argument), and that this dual behavior can naturally account for the variation found across dialects of Spanish. Finally, I have pointed in the direction of a new line of research by proposing that other well-known morphosyntactic alternations (apparently unrelated to clitic 
climbing) lend themselves quite readily to an account like the one set out here. These include alternations in case, auxiliary selection, and agreement, all of them stemming from two possible Merge orders in the derivation.

\section{References}

Authier, M. \& Reed, L. (2009). On the Lack of Transparency Effects in French. In P. Masullo, E. O'Rourke, \& C.-H. Huang, eds., Romance Linguistics 2007. Amsterdam/Philadelphia: John Benjamins, pp. 37-49.

Baker, M. (1988). Incorporation: A Theory of Grammatical Function Changing. University of Chicago Press.

Baker, M. (1996). The Polysynthesis Parameter. Oxford / New York: Oxford University Press.

Bertora, H. (2016). Ascenso de clíticos y Long-Distance Agreement como variantes del mismo fenómeno. In M. Pelliza, X. Picallo, \& S. Sayago, eds., LiteraturaLingüística: Investigaciones en la Patagonia IX. Comodoro Rivadavia: Editorial Universitaria de la Patagonia, pp. 50-7.

Bobaljik, Jonathan D. \& Phillips, Colin (1993) Papers on Case and Agreement I, MIT Working Papers in Liguistics, 18.

Burzio, L. (1986). Italian Syntax. Dordrecht: Reidel.

Cardinaletti, A. \& Shlonsky, U. (2004). Clitic Positions and Restructuring in Italian. Linguistic Inquiry, 35, 519-57.

Chomsky, N. (1995). The Minimalist Program. Cambridge, MA: MIT Press.

(2000). Minimalist Inquiries: The Framework. In R. Martin, D. Michaels, \& J. Uriagereka, eds., Step by Step: Essays on Minimalist Syntax in Honor of Howard Lasnik. Cambridge, MA.: MIT Press, pp. 89-156.

Cinque, G. (2004). Restructuring and Functional Structure. in A. Belletti, ed., Structures and Beyond: The Cartography of Syntactic Structures, vol. III. Oxford / New York: Oxford University Press, pp. 132-91.

(2006). Restructuring and Functional Heads: The Cartography of Syntactic Structures, vol. IV. Oxford / New York: Oxford University Press.

Contreras, H. \& Masullo, P. (1999). Hacia un algoritmo para la fusión sintáctica. Boletín de Filología, 37, 417-30.

(2002). Motivating Merge. In M. Leonetti, O. Fernández-Soriano, \& V. Escandell Vidal, eds., Current Issues in Generative Grammar: 10th Colloquium on Generative Grammar, 2000, Selected Papers. Universidad de Alcalá de Henares.

Guasti, M. T. (1997). Romance Causatives. In L. Haegeman, ed., The New Comparative Syntax. London: Longman, pp. 124-44.

Halpern, A. L. (1998). Clitics. In A. Spencer \& A. Zwicky, eds., The Handbook of Morphology. Oxford: Blackwell.

Hurtado, A. (1984). On the Properties of LF. Cornell Working Papers in Linguistics, 5, 121-49.

Jaeggli, O. (1986). Three Issues in the Theory of Clitics: Case, Doubled NPs, and Extraction in the Syntax of Pronominal Clitics. In H. Borer, ed., The Syntax of Pronominal Clitics, Syntax and Semantics, 19. Orlando: Academic Press, pp. $15-42$. 
Kayne, R. (1975). French Syntax: The Transformational Cycle. Cambridge, MA.: MIT Press.

(1989). Null Subjects and Clitic Climbing. In O. Jaeggli \& K. Safir, eds., The Null Subject Parameter. Dordrecht: Kluwer.

(1991). Romance Clitics, Verb Movement, and PRO, Linguistic Inquiry, 22, 647-86. Lipski, J. (1994). Latin American Spanish. London: Longman.

Masullo, P. (1990). Toward an Incorporation Account of Argument Alternations in Spanish (unpublished Master's thesis).

(1992a). Relativized Minimality and Logical Form. In K. Varden, ed., University of Washington Working Papers in Linguistics. University of Washington.

(1992b). Incorporation and Case Theory in Spanish: A Crosslinguistic Perspective (unpublished doctoral dissertation). Seattle: University of Washington.

(1998). Complex Predicates: A Direct Merge Analysis. Paper presented at the Australian Linguistics Society Meeting, University of Queensland, Brisbane, July 1998.

Perlmutter, D. (1983). Studies in Relational Grammar, vol. I.University of Chicago Press.

Phillips, C. (1993) Papers on Case and Agreement II, MIT Working Papers in Linguistics, 19.

Rizzi, L. (1990). Relativized Minimality. Cambridge, MA: MIT Press.

Saltarelli, M. (1989). Syntactic Shift and the Creation of Clitics in Romance. In J. De Cesaris \& C. Kirschner, eds., Studies in Romance Linguistics. Amsterdam: John Benjamins, pp. 347-64.

Sportiche, D. (1997). Subject Clitics in French and Romance, Complex Inversion and Clitic Doubling. In K. Johnson \& I. Roberts, eds., Studies in Comparative Syntax. Dordrecht: Kluwer.

Strozer, J. (1976). Clitics in Spanish (unpublished doctoral dissertation). University of California-Los Angeles.

Suñer, M. (1988). The Role of Agreement in Clitic-Doubled Constructions,. Natural Language and Linguistic Theory, 6, 391-434.

Uriagereka, J. (1995). Aspects of the Syntax of Clitic Placement in Western Romance, Linguistic Inquiry, 26, 79-123.

Zubizarreta, M. L. (1987). Levels of Representation in the Lexicon and in the Syntax. Dordrecht: Foris. 